\title{
The suspended load in the water-storage reservoir of the hydroelectric power plant Boštanj on the Sava River
}

\author{
B. Dolinar \& H. Vrecl-Kojc \\ Department of Geotechnical Engineering, Faculty of Civil Engineering, \\ University of Maribor, Slovenia
}

\begin{abstract}
This paper deals with the suspended load in the Sava River, which is the longest river in Slovenia. It flows for $220.7 \mathrm{~km}$ across a geologically, geographically and climatologically agitated area. The river supports a considerable electricityproduction potential. Besides the existing power plants, there are several hydroelectric plants under construction, of which "Boštanj” has just begun its production of electricity. The objective of the study described in this paper was to determine the concentration and composition of the suspended load in the reservoir of the hydroelectric power plant Boštanj. For this purpose, 24 water samples from the area of the water intake and the water outlet were taken. At the same time the flow rate of the river was measured. The solid particles were removed from the water with the help of sedimentation and, in the final stage, with water evaporation. With such an approach, a sufficient quantity of suspended material for further mineralogical and chemical analyses was ensured. The analysis showed that the quantity of the suspended load, for the same flow rate, was larger at the water intake than at the water outlet. The difference represents the material that sedimented in the lake due to the speed decrease of the water as a result of the river's impoundment. The sedimented material may be expressed in relation to the flow rate. A comparison of the structure of the samples from both sampling areas showed that at the water outlet there is a somewhat smaller share of carbonate grains and heavy minerals than at the water intake, and a higher content of organic detritus and clay particles can also be observed.
\end{abstract}

Keywords: suspended load, sedimentation, sediment transport, water storage reservoir. 


\section{Introduction}

The paper discusses the results from a survey of the suspended load in the reservoir of the hydroelectric power plant (HPP) Boštanj at the Sava River [3]. The concentration and the particle size of the suspended load and its mineral and chemical composition were examined. On the basis of these data, the total quantity and the type of sedimented material in the reservoir were assessed [1].

\section{Sampling procedure}

The water samples, from which the suspended material was removed, were taken at the water intake and water outlet of the HPP Boštanj reservoir (fig. 1). To ensure the comparability of the data, the water samples were always taken at the same site and at the same depth of $1 \mathrm{~m}$. A total of 24 samples were collected, each containing at least 401 of water. At the site of the sample collection the discharge of the Sava River and its temperature were examined during the sampling (table 1).

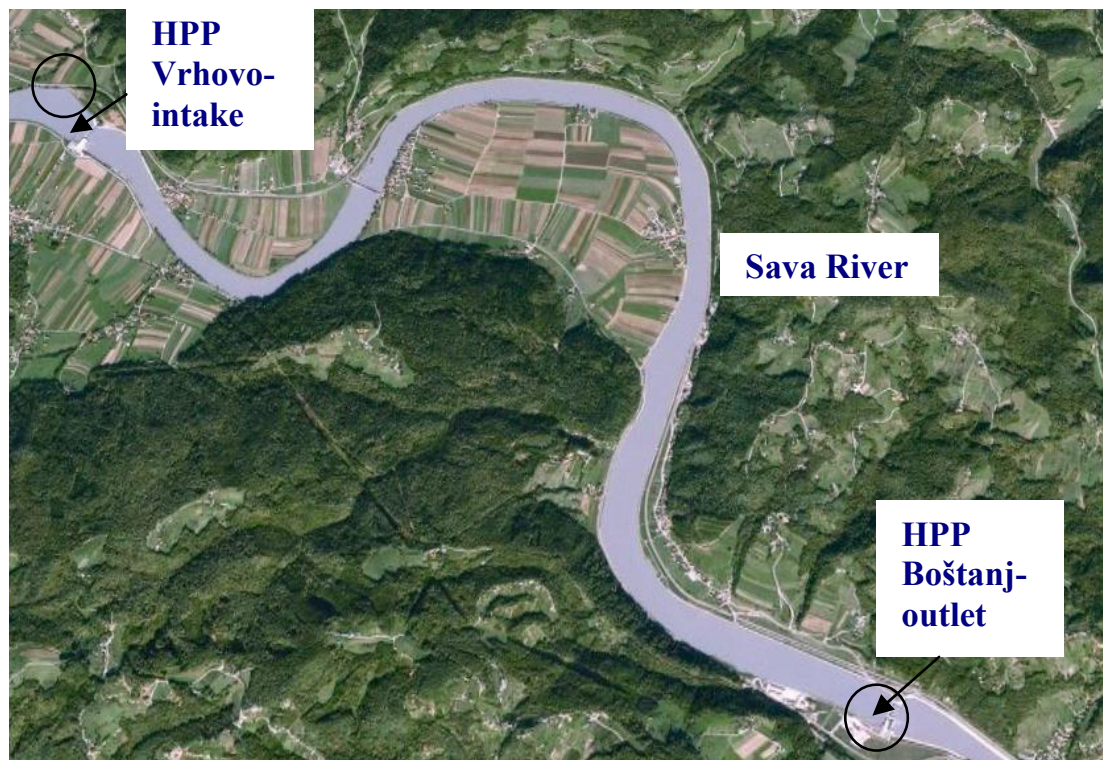

Figure 1: $\quad$ Reservoir of the HPP Boštanj.

The concentration of the suspended load in the water was estimated at the Soil Mechanics Laboratory at the Faculty of Civil Engineering in Maribor. The solid material was removed from the water with the help of the sedimentation of the particles and the water evaporation. 
Table 1: $\quad$ Sampling date, temperature of the water $(T)$, discharge $(\mathrm{Q})$, and concentration of suspended load (c).

\begin{tabular}{|c|c|c|c|c|}
\hline Sample & Date & $\mathrm{T}\left({ }^{\circ} \mathrm{C}\right)$ & $\mathrm{Q}\left(\mathrm{m}^{3} / \mathrm{s}\right)$ & $\mathrm{c}\left(\mathrm{g} / \mathrm{m}^{3}\right)$ \\
\hline 1 Water intake & 01.09 .2006 & 13.3 & 175 & 6.8 \\
\hline 1 Water outlet & & 16.6 & 152 & 1.1 \\
\hline 2 Water intake & 20.09 .2006 & 13.0 & 252 & 12.7 \\
\hline 2 Water outlet & & 13.0 & 252 & 8.6 \\
\hline 3 Water intake & 26.10 .2006 & 12.0 & 248 & 19.6 \\
\hline 3 Water outlet & & 12.5 & 264 & 10.0 \\
\hline 4 Water intake & 15.11 .2006 & 9.5 & 65 & 1.7 \\
\hline 4 Water outlet & & 9.5 & 61 & 0.8 \\
\hline 5 Water intake & 23.11 .2006 & 10.0 & 210 & 18.3 \\
\hline 5 Water outlet & & 10.0 & 180 & 18.3 \\
\hline 6 Water intake & 24. 11. 2006 & 10.0 & 134 & 5.8 \\
\hline 6 Water outlet & & 10.0 & 130 & 8.3 \\
\hline 7 Water intake & 11. 12.2006 & 9.5 & 407 & 47.5 \\
\hline 7 Water outlet & & 9.5 & 383 & 25.0 \\
\hline 8 Water intake & 24. 01.2007 & 7.0 & 478 & 75.4 \\
\hline 8 Water outlet & & 9.0 & 525 & 40.8 \\
\hline 9 Water intake & 09.03 .2007 & 10.0 & 340 & 15.8 \\
\hline 9 Water outlet & & 10.0 & 316 & 11.3 \\
\hline 10 Water intake & 24. 04. 2007 & 15.0 & 100 & 6.6 \\
\hline 10 Water outlet & & 15.0 & 114 & 0.8 \\
\hline 11 Water intake & 21.05 .2007 & 17.0 & 74 & 1.7 \\
\hline 11 Water outlet & & 17.0 & 63 & 5.8 \\
\hline 12 Water intake & 05.06 .2007 & 19.5 & 79 & 5.2 \\
\hline 12 Water outlet & & 19.5 & 62 & 3.7 \\
\hline
\end{tabular}

\section{Laboratory investigations}

The size of the particles was determined by the Geological Survey of Slovenia using a laser particle sizer "analysette 22"/ Nano Tec made by FRITSCH GmbH - Manufacturers of Laboratory Instruments, Germany. Analytical instruments based on laser diffraction for the determination of a particle size distribution use the physical principle of the scattering of electromagnetic waves. The design consists of a laser beam directed through a measuring cell to a detector. A dispersion module transports the particles to the measuring cell and through the laser beam. The light scattered in proportion to the particle size is projected by a lens onto a detector. The particle size distribution can then be calculated from the distribution of the scattered light with the help of complex mathematics. 


\section{Evaluation of the results}

\subsection{Particle size analysis of the suspended load}

A grain size analysis was performed for 16 samples from the intake and outflow area of the water from the reservoir. The samples from both sampling sites were collected simultaneously, and therefore they refer to the same discharge. In this way it is possible to compare the particle sizes in the suspension with regard to the sampling site. The results of the analyses show that the suspended load mostly has the size of silt, and only $5-20 \%$ of the grains belong to the clay fraction. Larger grains were found at the water-intake site, while an increased share of the clay fraction was observed at the outflow.

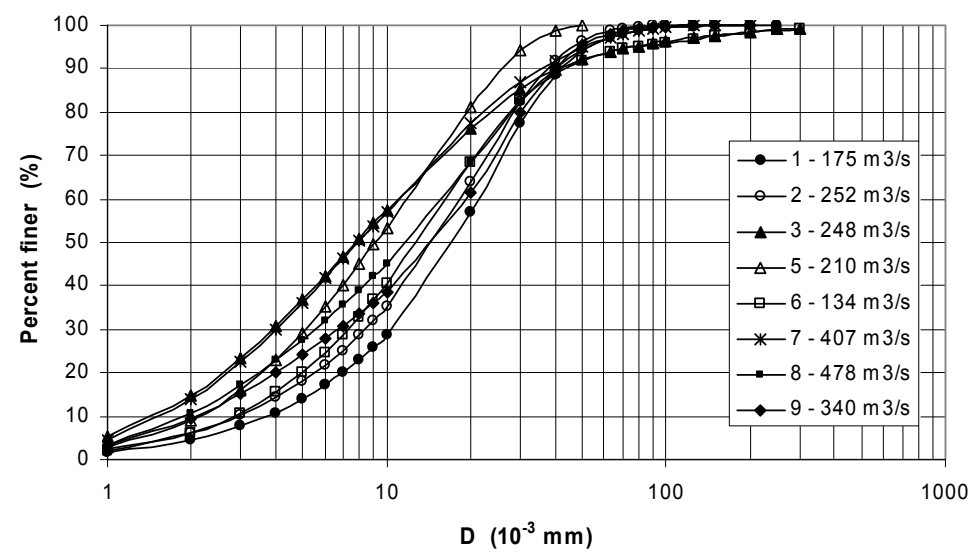

Figure 2: Grain size distribution of the suspended load at the water intake of the HPP Boštanj reservoir. The legend indicates the discharges for the different sampling periods.

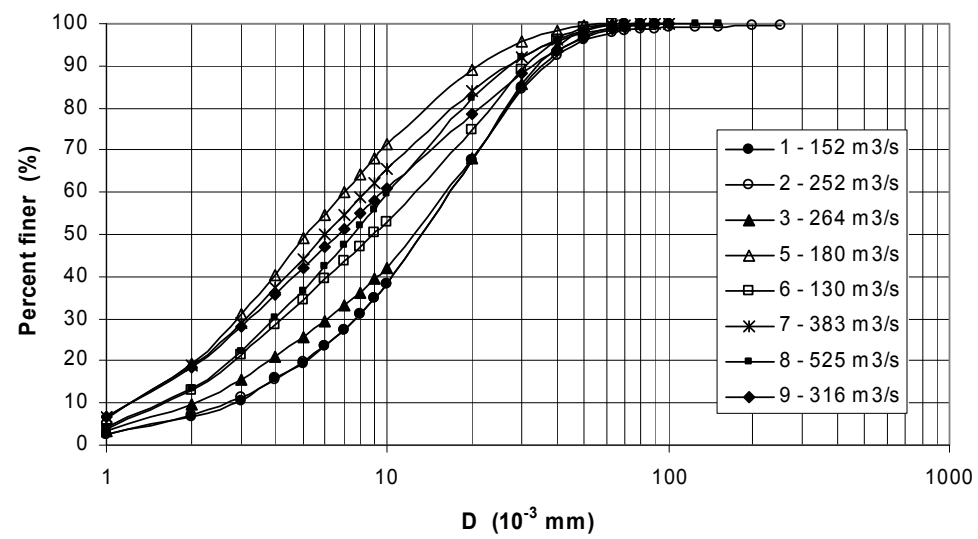

Figure 3: Grain size distribution of suspended load at the outflow of the water from the reservoir of the HPP Boštanj. 


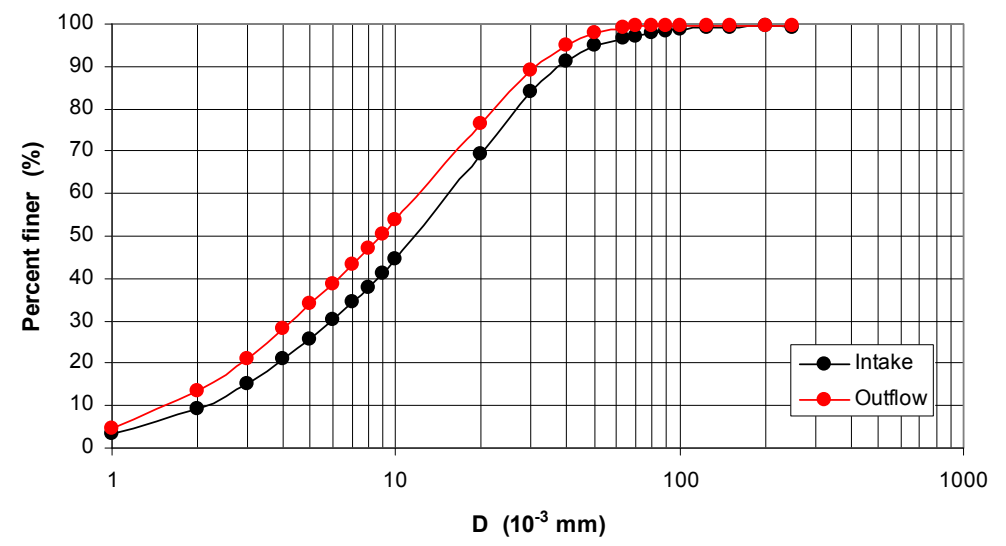

Figure 4: Comparison of the grain sizes of the composed samples of solids from the intake and the outlet area of the water from the reservoir.

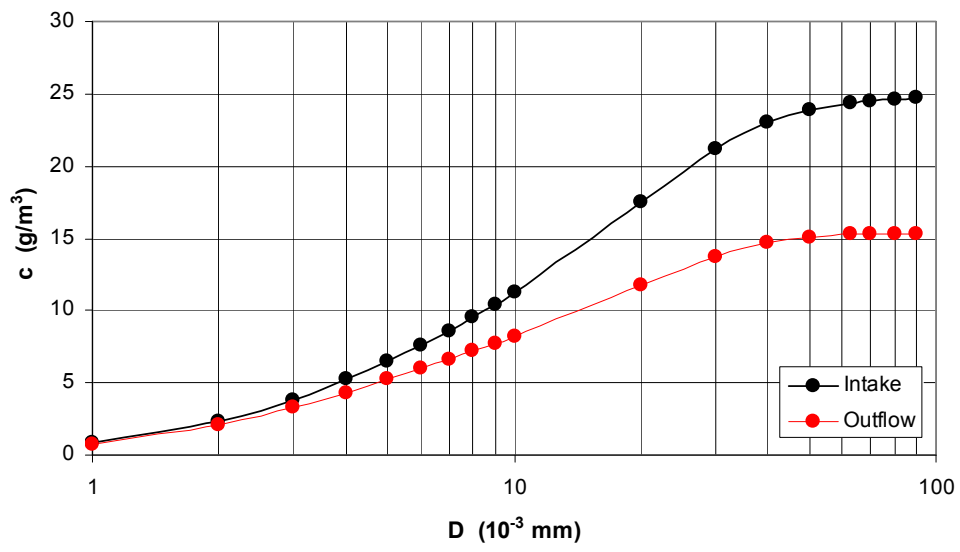

Figure 5: Relationship between the concentrations of the suspended load and the grain sizes of the composed samples from both collection sites.

Figs. 2 and 3 present the results of the grain size analysis for individual samples with respect to the discharges.

Fig. 4 presents the difference in the grain size of the suspended load between the water intake and the water outlet of the reservoir.

The ratio between the concentration of the suspended material $\left(\mathrm{g} / \mathrm{m}^{3}\right)$ and the grain size at the water intake and water outlet of the reservoir is presented in fig. 5 . It is evident that the quantity of larger grains $(10-100 \mu \mathrm{m})$ of the solids in the water is smaller at the outlet of the reservoir than at the intake. 


\subsection{Concentration of the suspended load}

The concentration of the suspended load in the watercourses depends on many factors, which is why a study of the dynamics of their transport and sedimentation is quite demanding [2]. However, at an individual measuring station we can see a correlation between the concentrations of the suspended material and the flow rates of the water [4].

The results of the measurements at selected sites of the reservoir of the HPP Boštanj showed that the share of suspended load is increasing with the increase of the discharge (table 1). This ratio is shown in fig. 6 , in which both variables are presented separately for the samples from the intake and the outflow site of the water from the reservoir. Due to an almost simultaneous collection of the samples from both sites, the discharge was very similar; however, there is a difference in the quantity of the suspended material, which is much smaller at the water outflow.

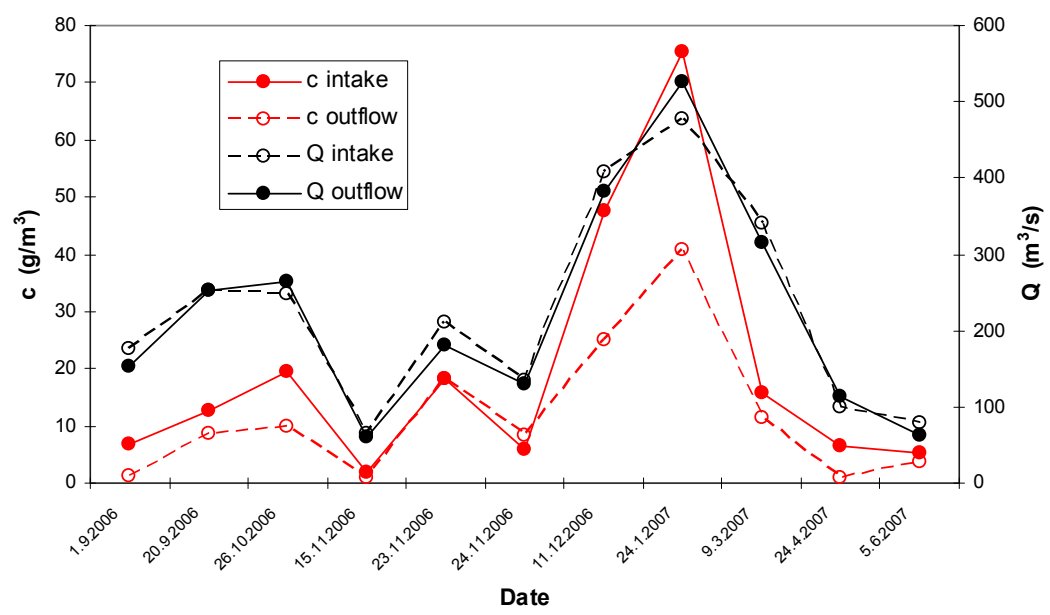

Figure 6: The concentration of suspended load in relation to the discharge and the time periods of the sample collection.

A comparison of the concentrations of the suspended load from both collection sites showed that this ratio is approximately linear (fig. 7). We can describe it with eqn (1).

$$
c_{\text {ouflow }}=0.55 \cdot c_{\text {int ake }}
$$

It apparent from the presentation of the suspended load concentrations at the water intake and outflow, and the discharges (figs. 8-9), that it is possible to describe these ratios with eqns (2) and (3).

$$
\begin{aligned}
& c_{\text {int ake }}=1.85 \cdot e^{0,007 Q}\left(\mathrm{~g} / \mathrm{m}^{3}\right) \\
& c_{\text {oufflow }}=1.45 \cdot e^{0,007 Q}\left(\mathrm{~g} / \mathrm{m}^{3}\right)
\end{aligned}
$$




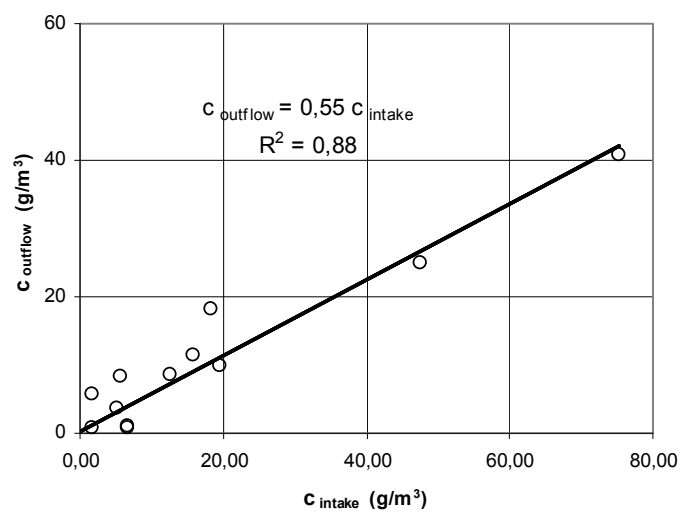

Figure 7: Ratio between the concentrations of the suspended load at the water intake and at the water outlet of the reservoir.

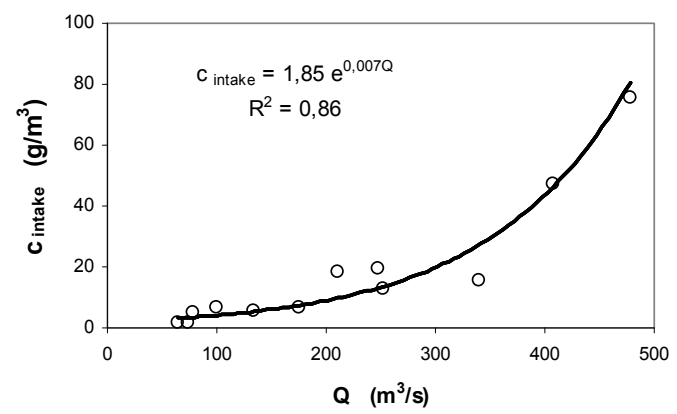

Figure 8: The concentration of suspended load in relation to the discharge at the intake of the water from the reservoir of the HPP Boštanj.

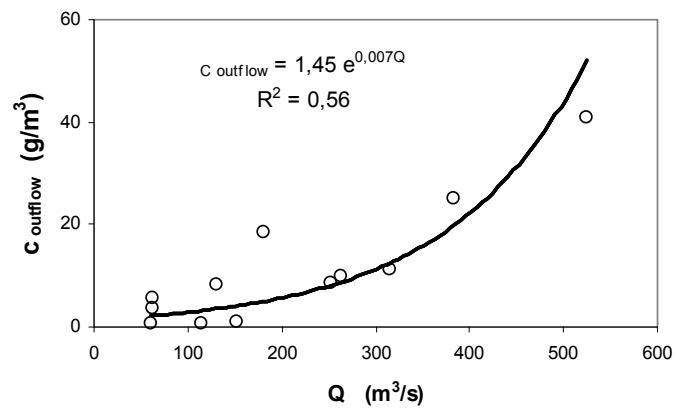

Figure 9: The concentration of suspended load in relation to the discharge at the outflow of the water from the reservoir of the HPP Boštanj. 


\subsection{Estimation of the quantity of deposited material}

The studies of the concentrations of the suspended load at both sampling sites showed that there is less suspended load at the water outlet than at the water intake. The difference represents the material that sedimented. By considering eqns (2) and (3) the quantity of these sediments $\left(\mathrm{c}_{\mathrm{sed}}\right)$ can be expressed in relation to the discharge of water with eqn (4).

$$
c_{\text {sed }}=c_{\text {int } a k e}-c_{\text {outflow }}=1.85 \cdot e^{0.007 Q}-1.45 \cdot e^{0.007 Q}=0.4 \cdot e^{0.007 Q}
$$

An estimation of the quantity of deposited material in the reservoir was prepared on the basis of the actual hourly discharges for the period between 12 July 2006 and 12 July 2007 (fig. 10). Considering the volume of water flowing through and the portion of deposited material in dependence on the actual discharges, see eqn (4), the estimated quantity of the deposited material in the reservoir is $1.08 \times 10^{4} \mathrm{t}$ for the selected period of time.

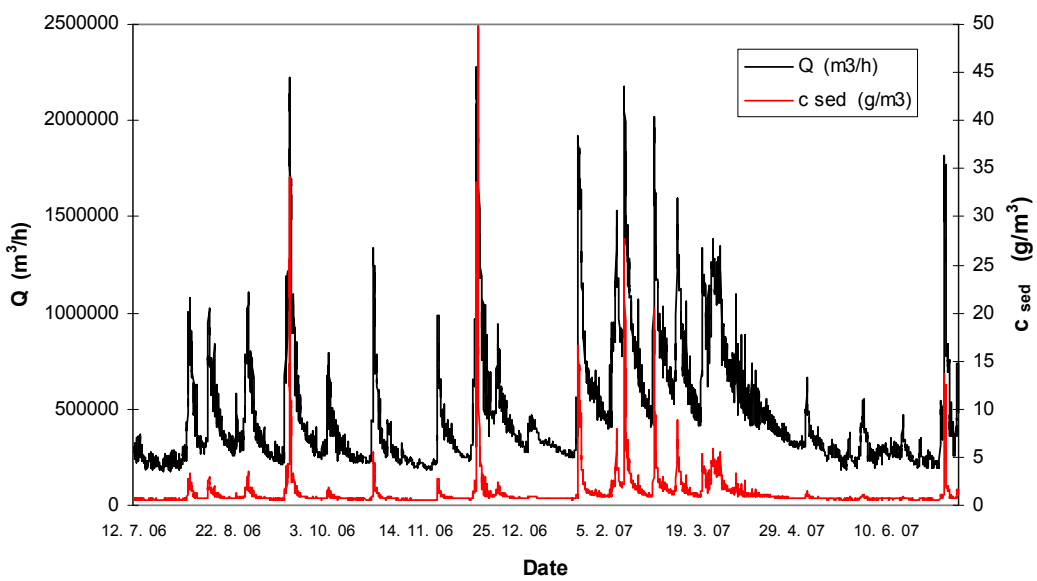

Figure 10: The discharge and the quantity of deposited material for the period of one year.

\section{Conclusions}

This paper deals with the sedimentation of suspended material in the reservoir of the hydroelectric power plant Boštanj on the Sava River. The objective of the described research was to determine the quantity and type of sedimented material in the reservoir during the selected time period. For this purpose, the concentration and the particle size of the suspended load at the intake of the water into the reservoir and at its outflow were examined. On the basis of the gathered data, the following conclusions can be established.

Because of the changed geometry of the riverbed and, consequently, the lower speed of the water, part of the suspended load is sedimented on the bottom of the 
reservoir. Based on a comparison of the average quantities of the solids in the water at the intake and the outflow, it is evident that at the same flow rate of water this ratio is approximately linear, see eqn (1). The concentration of the suspended load increases with an increase in the water discharge; however, this increase is not linear. This dependence can be expressed for the samples of both collection sites with exponential functions. The quantity of sedimented particles depends mostly on the discharge of the water. This ratio in the examined case can be described with eqn (4). The estimated quantity of sedimented material in a period of one year amounts to $1.08 \times 10^{4} \mathrm{t}$. However, the actual quantity of this material in the reservoir was lower due to its transport at very high discharges of water.

Based on the ratio between the concentration of the suspended load and the size of the grains at the intake and the outflow of the water, it can be concluded that the particles, especially those with a size between $10 \mu \mathrm{m}$ and $100 \mu \mathrm{m}$, are sinking.

A similar procedure for estimating the sedimented material in a reservoir was also performed for a planned pumped-storage hydroelectric power plant on the Drava River in Slovenia [5].

\section{References}

[1] Dolinar, B., Vrecl-Kojc, H., Trauner, L. Analysis of concentration and sedimentation of suspended load in the reservoirs, Acta Geotechnica Slovenica, 5 (2), pp. 30-39, 2008.

[2] Rusjan, S. And Mikoš, M. Suspended load transport dynamics in river basins. Acta hydrotechnica, 40, 1-20, 2006.

[3] Trauner, L., Škrabl, S., Žlender, B., Dolinar, B., Macuh, B., Vrecl-Kojc, H., Šketelj, E., Petrešin, E., Jecl, R., Nekrep, M., Lobnik, A., Poberžnik, M., Turel, M., Zlatolas, D., Greifoner, R., Bauman, M., Senica, H. Development of the technology to remove sediments and debris before the accumulation dams: development and investment project. The final report. Faculty of Civil Engineering, Maribor, 2007.

[4] Ulaga, F. The content and transport of suspended material in the Slovenian rivers. Environmental Agency of the Republic of Slovenia, 2005.

[5] Vrecl-Kojc, H., Dolinar, B., Klasinc, R., Trauner, L. Analyses of the suspended-load sedimentation process and its dynamics in reservoirs with high daily oscillations, Acta geotechnica Slovenica, 5 (2), pp. 41 - 49, 2008. 